\title{
Lok Vanaki - a recent innovative approach for managing private forestry in Madhya Pradesh, India
}

\begin{abstract}
A K Bhattacharya ${ }^{1}$ and Bijendra Basnyat ${ }^{2}$
This paper highlights on Lok Vanaki (private forestry) scheme, an innovative and decentralized approach for managing private forestry of Madhya Pradesh (MP) and examines on policy provisions, implementation status and explore on issues associated with its implementation. This scheme was launched in Madhya Pradesh in April 1999 for promoting multi-tier scientific management of neglected and degrading forests on private holdings. The State Government has taken adequate measures to provide sufficient legal support to the whole initiative. Lok vanaki has not only helped on conservation and development of private forestry but also in socio-economic upliftment of people. It has also contributed in reducing the unemployment rate of the country concept through the charter foresters, who are fully authorized for preparation, implementation and monitoring of the plan. Efforts are underway to make the programme successful through political commitment.
\end{abstract}

Keywords : Private forestry, Forest acts, Management plan, MP, India.

\section{Evolution of concept}

Rapid population, growth has created a demand and supply gap for the forestry products. The gap of fuelwood was 9.75 Million cubic meters in 1999 (MPFD, 1999). Apart from this, the productivity of the forest resources is decreasing day-by-day due to over dependency on forest products. This has created a tremendous pressure in government forest, which had lead to their degradation, Singh (1998) estimated that 14 forest-based industries in the state have been closed due to shortage of raw materials and many others are operating below their installed capacity. In addition to above, Verdict of Honorable Supreme Court on 12-12-96 states that felling of trees in all forests (including private forests) is banned except in accordance with approved working (management) plans. Hence, it has been felt that there is an imperative need to shift the wood production functions from natural forests under forest development to private forest and wasteland in order to make the Governmental forest to play the ecological role exclusively.

As a result, the Govt. of M P conducted a thorough study and discussion with farmers and officials in order to hammer out a programme to promote tree growing in the revenue area and private holdings, which generally fall in the category of wasteland. The Govt. of M P launched "Lok Vaniki (private forestry) Mission" a programme to promote tree growing in private holding and revenue area with people's participation in April 1999. Initially, the programme was lunched in four districts on a pilot basis, which has now been extended to 10 districts. The chronological event of evolution of Lok Vanki is summarized in Table 1.

Table 1: Evolution of Lok Vanaki in MP

\begin{tabular}{ll}
\hline Years & \multicolumn{1}{c}{ Chronological events } \\
\hline 1996 & Supreme Court's verdict against felling of green trees \\
1999 & - Launched the private forestry concept in Madhya Pradesh and opening of Lok Vanaki Cell under \\
& Lok Vaniki with Additional PCCF (Production) as the mission leader. \\
& - Decided to implement in four districts of MP \\
& - A high-powered committee composed of senior officials from the Panchayat, Tribal, Forest and Revenue \\
& departments was set up to look into legal requirements of the Lok Vaniki scheme. \\
2000 & Scheme was extended to three more districts \\
2001 & Formulation of Lok Vanaki Act
\end{tabular}

1 Conservator of Forests, Madhya Pradesh Forest Department, MP, India. Email: ajoykb@sancharnet.in

${ }^{2}$ Senior Research Officer, NARMA Consultancy Pvt. Ltd. Post Box 13536, Kathmandu, Nepal:

Email: bijendra@narma.org.np; bbasnyat@yahoo.com 


\section{The scheme}

Lok Vanki is an innovative programme launched in MP in April 1999. The concept contemplates capturing the inter-relationship between economic growth, environmental preservation and poverty alleviation through development of forestry in the private sector. The major focus of the scheme is on promoting multi-tier scientific management of neglected and degrading forests on private holdings and also inculcating a culture of tree cultivation. The vision statement, envisaged as "Lok Vaniki : Vision $2020 "$, states -

'To transform the forestry Sector in MP, so as to enable it to fulfill its dual role of maintaining ecological balance and environmental stability while simultaneously meeting not only the domestic demand but also a share of the international market of forest products through people's participation thereby contributing to the socio-economic development of the State'.

\section{Lok Vaniki aims to}

- Increased production of wood and non-wood forest products in the private sector by managing and harvesting standing forests on private holdings; rehabilitating degraded forests on private holdings and on lands under the control of Government departments (other than Forest Department) mainly Revenue Department; plantations on private and Revenue Department wastelands.

- Empowering and strengthening of Panchayats and creation of other necessary institutions like 'Kisan Sangh' and 'Chartered Foresters' to manage, supervise and monitor forestry and forest based activities as also tax collection in Non-Government sector.

Hence, Lok Vanaki is initiated for the scientific management of private forests and promotion of tree cultivation on marginal lands. This would be achieved by providing suitable legal, institutional and market environment. The Lok Vanaki management process can be summairzed as below in box 1 .

\section{Policy and legal measures}

The State Government has taken adequate measures to provide sufficient legal support to the whole initiative. Lok Vanaki Act, 1999 and Lok Vanaki Rule 2001 has been formulated which provided an enabling legal framework to people willing to manage forests and tree clads area on scientific lines. The objectives of the Act are to regulate and facilitate management of tree clad private and revenue areas in the state of Madhya Pradesh. Lok Vaniki, which emerged after the historic decision of the Hon'ble Supreme Court has now assumed a shape that is based on sound legal grounds. Key features of Lok Vanaki legislation are summarized in box 2 .

In order to facilitate tree cultivation and harvesting in a decentralized yet systematic and sustainable manner, peoples' institutions are being entrusted with implementation responsibilities. Institutions like "Lok Vaniki Kisan Uddyami Sangh" are being registered under the Societies Act. The objective of the Kisan Sangh (Farmers' association) is to bring all small farmers together to organize for collective action in the field of private forestry and provide forward and backward linkages to its members, which are inevitable for multi-tier forestry. One of the other major objectives of the Kisan Sangh is to generate funds to make available the advance technology to the farmers and also facilitate proper marketing of timber and non-wood forest produce. Forestry Boards at State and District level are also being constituted to supervise various aspects of private forestry. The State Govt. has recently created a new institution of Chartered Foresters to ensure

\section{Box 1: Procedural steps for managing private forestry under "Lok Vanaki "}

- Making the farmers aware of the concept, benefits to them through implementation of the scheme and their responsibilities.

- They are told that the land cannot be diverted for any other use.

- Land has to be clearly demarcated and certificates obtained from Forest and Revenue departments that no forest or government land has been included in their holding.

- A management plan has to be prepared and approved by a competent authority.

- Trees to be felled are marked strictly in accordance with the approved management plan.

- Regeneration of forest has to be ensured.

- Regular monitoring will take place and implementation of the management plan will be suspended if working is not found complying with management plan. All illicitly felled trees will be confiscated. 


\section{Box 2: Key Features of Lok Vanaki Legislation}

- Fairly free from Colonial Shadows:

- An Enabling Law -voluntary in application: Private forest owners voluntarily prepared plan for managing their wood lots

- Preparation of management plan: Management plan is prepared to ensure continuity and improvement of the forest so that it fulfills its environmental and economic roles optimally. In preparing the management plan of private forests, the same silvicultural principles are applied as in the case of government forests

- Chartered Foresters: Availability of Technical Forestry Services to People on commercial basis. These are the private independent parties who will prepare the management plan for the farmer for sustainable management of private forest

- Putting People First: Self Assessment by the Owner of Private Forests the Act itself is very progressive, the process for framing rules under the Act was also participatory

- Single Window deals with the issue of management of such private holdings for which a management plan is prepared under the provisions of the Act. Such lands shall remain outside the purview of the Madhya Pradesh Land

- Recognition of role of local government in Sustainable Private Forestry: The Gram Panchayat after having received the approved management plan from the competent authority should implement the plan according to prescribed time schedule.

- Institutional framework: State-level Coordination Committee, Forestry Boards at district and block-level, Lok Vaniki Kisan Samiti and Sangh and Chartered Foresters, Kisan Sangh' and Chartered Foresters to manage, supervise and monitor forestry and forest-based activities

availability of technical assistance in the field of forestry on commercial basis. Till to date, sevenchartered forester has already registered with Lok Vanaki Cell. Panchayat Raj Institutions, especially Gram Sabhas are supposed to play a major role in implementation and monitoring of private management plans.

\section{Implementation status}

The Lok Vanaki was initiated in four districts but now it covers ten districts namely, Devas, Hoshangaad, Damo, Sivni, Narsinghpur, Jabalpur, Kanti, Mandala, Dindori, Sidhi. Until now 1196 farmers owning 4211 hectares of land from five districts have got involved in the scheme (Saigel et al, 2002). The State Govt. has made elaborate arrangements for training and capacity building of these peoples institutions to evolve a transparent and convenient mechanism for private peoples active participation in management of their own tree clad areas. More than 150 training programs have been organized in 10 districts and 20,000 farmers are trained on various aspects of forest management with the introductory module of Lok Vanaki legislation. Fifty management plan of Lok Vanaki have already been prepared of which four are being sanctioned and three has been forwarded to Govt of India for approval as the plans cover more than 10 ha of land. In anticipation of the income that would be generated, many farmers invested in raising of plantations to further increase their assets. As per available information, approximately 3,79,000 seedlings were planted in 1999 planting season in Dewas, Sidhi and Raigarh districts only. Three farmers have started harvesting and their name and annual income is summarized in table 2 below.

\section{Conclusions}

Lok Vanaki is a decentralized approach adopted by Madhya Pradesh Forest Department where the role of Panchayat has been duly acknowledged. The concept of charter forester is not only innovative but could also contribute in reducing the unemployment. The farmers can make this productive without much

Table 2: Income from Lok Vanaki

\begin{tabular}{llcc}
\hline \multicolumn{1}{c}{ District } & \multicolumn{1}{c}{ Name of farmer } & Annual income & Total forest area \\
\hline Hosangabad & Kanta Prasad Mahoto & Rs 97,705 & 3.05 ha \\
Devas & Shodara Rai & Rs 18.788 & 1 ha \\
Damo & Kodulal Dubey & Rs 18,788 & 0.8 ha \\
\hline
\end{tabular}


investment (Saigel et. al, 2002). This would not only help for conservation and development of private forestry but also in socio-economic upliftment of people. Since this is a new programme, rectification in various aspects of implementation is needed. Important among them is to expedite the handing over, which is very slow due to long administrative procedures. It requires approval from Central government if the area is more than 10 ha of land. Hence, Lok Vanaki is not a panacea but it can contribute a lot towards sustainable management of private forests if properly implemented.

\section{References}

GOMP. 2002. Madhya Pradesh Lok Vanaki Act-2001, and Madhya Pradesh Lok Vanaki Rule - 2002. Madhya Pradesh Government, Bhopal, MP, India MPFD.1999. Madhya Pradesh Forestry Action Plan. Madhya Pradesh Forest Department, Bhopal India Saigal, S, Arora, H and Rizvi, S.S. 2002. The new foresters: the role of private enterprise in the Indian forestry sector. Instruments for sustainable private sector forestry series. Ecotech Services, New Delhi and International Institute for Environment and Development, London

Singh, D.P. 1998. Socio-economic Development of Madhya Pradesh through Forestry by the people, for the people. Government of Madhya Pradesh, Bhopal, India 